\title{
Paulina KUBERA
}

DOI : $10.14746 / \mathrm{pp} .2017 .22 .4 .3$

Poznan University of Technology

\section{A new approach to policy evaluation in the European Union}

\begin{abstract}
The significant role of the European Union in diffusion of evaluation in Europe is widely acknowledged (Stern, 2009). Although evaluation has a long-standing tradition in the EU, and in particular within the European Commission, in recent years one can observe the process of its expansion, diversification and institutionalisation.

The aim of the paper is to explore the new developments in evaluation policy in the EU, which can be characterised, among others, by strengthening the links between ex ante and ex post impact evaluations and thus closing the policy cycle, where ex post evaluation feeds into ex ante assessment of new public actions. Hence, the problem of utilisation of evaluation findings is discussed. The scope of evaluation performed at the EU level has also been extended from expenditure to regulatory instruments. Moreover, there has been a shift from evaluating merely projects and programmes to evaluating policies and aggregated activities. To this end, a literature and documentary review on evaluation theory and practice have been conducted, as well as the analysis of the normative provisions that are applied to guide the practice of evaluation in the EU.
\end{abstract}

Key words: evaluation, evidence-based policy making, use of evaluation findings, better regulation

\section{Introduction}

$\mathbf{T}$ he concept of the public policy cycle divides the policy process into a series of stages, starting from the identification of a problem that needs public intervention (agenda setting), defining the possible solutions and public policy tools to address the identified problem (policy formulation), choosing one of the alternatives (decision-making), its implementation and evaluation, that is - assessing the extent to which the policy (programme, a new regulation), actually solves the problem, what the general costs and benefits of the policy are, as well as the indirect and unintended effects. On this basis, it is decided whether the policy should be continued, modified or discontinued. It is also the initial stage of a new policy cycle, as the lessons learned in the past influence the agenda setting and choices to be made in the future, thus closing the loop of the cycle. Although there are some differences in the literature concerning the number of stages, the idea is that public policy making should be seen as a continuous process rather than a single event (Versluis, van Keulen, Stephenson, 2011; Cairney, 2012). From this perspective, evaluation plays an important role in evidence-based policy-making and policy learning, however it is not always fully utilised.

Although evaluation has a long-standing tradition in the EU, and in particular within the European Commission, in recent years one can observe the process of its expansion, diversification and institutionalisation. Thus, the aim of the paper is to explore the new developments in evaluation policy in the EU. To this end, a literature and documentary review on evaluation theory and practice have been conducted, as well as the analysis of the relevant EU normative provisions. 
The article is organised into three sections. First, it explains the role of evaluation in the public policy cycle, its possible functions and the interplay between evaluation, monitoring and audit, which are distinct processes, which, however, feed into the evaluation process. Second, it deals with the problem of linking ex post evaluations with ex ante assessments, relating challenges and factors affecting the use of evaluation findings. Third, it analyses EU practices with the evaluation of regulatory policy, which is the EU's new leitmotif.

\section{Evaluation and its role in the public policy cycle}

The term 'evaluation' in the Encyclopedia of Evaluation is defined as "an applied inquiry process for collecting and synthesizing evidence that culminates in conclusions about the state of affairs, value, merit, worth, significance, or quality of a program, product, person, policy, proposal, or plan." The important feature of evaluation is that "conclusions made in evaluations encompass both an empirical aspect (that something is the case) and a normative aspect (judgment about the value of something). It is the value feature that distinguishes evaluation from other types of inquiry, such as basic science research" (Fournier, 2005, p. 140).

In the literature, two important aspects of the evaluation process are highlighted. First, it is the analytical and systemic character of evaluation studies, and the application of scientific approach and rigour in the methodology (Ferry, Olejniczak, 2008; Langbein, Felbinger, 2006; Patton, 2004). The aim of an evaluation is to provide reliable information which can be used in the decision-making process and improve the implementation of public interventions (policies, strategies, programmes or projects). Therefore, the second important aspect of evaluation is its utilitarian character (Bienias, Gapski, Jąkalski, Lewandowska, Opałka, Strzęboszewski, 2012). Evaluation is performed in order to ensure: sound evidence and learning; accountability, transparency and participation; policy coherence; and reducing the regulatory burden (European Commission, 2015).

Depending on the purpose of evaluation, we can distinguish two basic types of evaluation: ${ }^{1}$ a formative evaluation, which examines the organisational context, personnel, procedures, inputs etc. in order to improve the intervention design; and summative evaluation which examines the effects of public intervention. Special attention is paid in EU policies to the latter one. The European Commission in its Communication on "Public consultation on Commission Guidelines for Evaluation" characterises evaluation as "a critical, evidence-based judgement of whether an intervention has met the needs it aimed to satisfy and actually achieved its expected effects. It goes beyond an assessment of whether something happened or not, and looks at causality - whether the action taken by a given party altered behaviours and led to the expected changes and/or any other unintended or unexpected changes." With reference to the EU's actions - "as a minimum, an evaluation should look at the effectiveness, efficiency, coherence, EU-added value and relevance of an intervention or justify why this is not the case" (European Commis-

${ }^{1}$ Sometimes a third type of evaluation is added to the formative/summative dichotomy - developmental evaluation, which primary focus is on exploring possibilities and experimenting, rather than arriving at a fixed intervention. 
sion, 2013a, p. 13). The evaluation of socio-economic development in general, includes judgement criteria which fall into the following categories: relevance, effectiveness, efficiency, utility and sustainability (EVALSED, 2013).

Evaluation, monitoring and audit are complementary, but quite different exercises. Monitoring is, contrary to evaluation, a systematic, continuous process carried out during the duration of the intervention (and some time after its completion). It generates quantitative data on the implementation of the intervention, albeit, not generally on its effects (unlike evaluation, it does not take into account the outcomes and longer term impact of the intervention). Its aim is to track the progress of a public action and take remedial measures in the case of a deviation from the operational objectives. Thus, monitoring improves the performance of a public project, programme etc., and, by providing relevant factual data, facilitates subsequent evaluation (European Commission, 2015; Olejniczak, 2007; Olejniczak, Ferry, 2008). It differs from formative evaluation in the regularity of the process and the depth of the analysis (see: Markiewicz, Patrick, 2016).

Audit in the public sector has traditionally focused on financial reporting and compliance with the rules. In this case, the centre of interest for the auditors is the effectiveness of the management and internal control system (a so-called compliance audit). However, with the development of the performance audit, which goes beyond the questions of legality and sound financial management, the distinction between evaluation and audit has become less obvious. They both examine the policy design, implementation processes and their consequences, require similar knowledge and skills, and apply much the same methods. However, an audit has a stronger focus on how the work has been done to achieve the desired objectives, with special attention paid to the economy, efficiency and effectiveness of public actions, while an evaluation also seeks to answer the questions of whether the observed effects are due to a specific public intervention and why this public intervention has been more or less successful. It takes a broader perspective - examines the economic, social and environmental aspects of the intervention and compares this with other policy alternatives (Simismans, 2015; European Commission, 2013).

Although evaluation has a relatively long tradition in the European Commission (1980s), it used to be restricted to the EU expenditure programmes (under cohesion policy, common agriculture policy or development aid) and developed within different Directorates-General (Departments) of the European Commission. The increase in the EU budget and, consequently, EU expenditure, instances of corruption and misuse of the EU funds as well as legitimacy crises led to a more systematic approach towards evaluation in the Commission (see more: Højlund, 2015). Recent developments in evaluation policy in the EU can be characterised by the following three features: (1) greater emphasis placed on the use of evaluation, in particular, as an input into policy-making; by the introduction of the evaluate first principle, evaluation has been placed firmly within the policy cycle; (2) evaluation has been extended from expenditure policies to other types of public interventions, in particular, regulatory activities; evaluation has been embedded within better-regulations-initiatives; (3) a shift from evaluating merely projects and programmes to evaluating policies and aggregated activities (e.g. fitness checks). 


\section{Utilisation of evaluation findings}

As the Commission states in its Communication "Strengthening the foundations of Smart Regulation - improving evaluation (2013): changes are costly and take time to implement - so they need to be justified and greater attention needs to be paid to looking back before moving forward. Thus, the links between ex ante and ex post impact evaluations should be strengthened. This should be a continuous loop: a good evaluation should be influenced by the quality of the preparation which went into an intervention (i.e. the impact assessment); good impact assessments should draw on the lessons learnt from evaluations, which should identify problems, deficiencies, challenges and successes" (p. 5).

The new approach towards evaluation policy in the UE has been underpinned by the institutional reforms in the EU and a postulate for more citizen-based governance of the EU. It is worth noting that with the change of a paradigm of public administration from "the new public management," where inspiration has been drawn from private sector management techniques and market mechanisms, and citizens were perceived merely as clients of public services, to "the new public governance," civil society has become at the heart of public administration (Izdebski, 2007). As Boyte (2005, p. 536) put it: "[t]he shift involves a move from citizens as simply voters, volunteers and consumers to citizens as problem solvers and creators of public goods." In this new strand of development "government's role [is] to arrange and facilitate interactions processes within networks in a such a way that problems of under or non representation are properly addressed and interests are articulated and dealt in an open, transparent and balanced manner" (Klijn, Koppenjan, 2000, p. 135).

This altered viewpoint implies the application of relevant approaches and techniques in the evaluation process. Also the usefulness of evaluation should be considered in close relation with the expectations towards it, which have been reshaped along with reforms implemented in public administrations. Therefore, in the literature, apart from considering the use of evaluation in the strict sense, i.e. as a learning tool, broader implications of evaluation are discussed. The following different types of evaluation use are distinguished, where the first three represent use of evaluation findings and the last two - evaluation influence: (1) instrumental use (to modify the object of the evaluation, directly improve programming); (2) enlightenment use (conceptual use and reflective use; to generate knowledge about the type of intervention under study or generally in the field of interest); (3) symbolic use (to fulfil a requirement to perform evaluation); as well as (4) persuasive use (to legitimise or criticise an intervention) and (5) process use (to better understand both the object of evaluation and evaluation process, however, this is achieved through engagement in the evaluation process not merely on the basis on the evaluation findings), (for a review, see: Mayne, 2014). It has been acknowledged that dialogue and interactions between the stakeholders in the course of evaluation process may enhance relational capital which is crucial in the new public governance paradigm.

In reference to the use of evaluation as input for setting policy priorities and policy formulation, de Laat and Williams (2015) indicate six crucial factors for fostering the use of evaluation. How qever, in practice, all of them might pose specific challenges that must be faced. These factors are:

1) timeliness of evaluation in reference to the programme or policy cycle, since, for an evaluation to provide relevant advice and support decision-making at the strategic 
level and at the level of the design of a new intervention, it must be carried out within adequate time frame (however it might be challenging to find an adequate position on the trade-off between ensuring that evaluation results are available at a given point in programme or policy cycle and having the full picture of programme or policy impacts, as some of them may be observed in a longer time perspective);

2) building a good evaluation culture in an organisation, ensuring buy-in and ownership, securing support from senior management in the use of evaluation findings as it can improve their strategic use; this can be done, at least partially, by institutionalising evaluation within an organisation (however, there may be the risk that evaluation becomes a routine procedure),

3) evaluation quality - the fact that an evaluation is methodologically and empirically sound is important, however, that does not guarantee that recommendations will be followed up, therefore of the utmost importance is the approach taken to the evaluation, the involvement of stakeholders and the selection of the right evaluators together with evaluation and subject-matter expertise;

4) involvement of stakeholders, who should be divided into two groups: one group, which will be closely involved in the concrete follow-up, and the other, which will be more broadly concerned with evaluation findings; different forms of stakeholder involvement should be foreseen for both of these groups, from empowerment and participation, to merely consultation (however, the identification of stakeholders in the case of policy evaluation is much more challenging in comparison with project or programme evaluation);

5) fit with an organisation, its broader policy processes as well as the setting/context that evaluation relates to;

6) complementarity with other methods, tools to support decision-making.

Studies conducted on the use of evaluation findings in Poland in reference to EU programmes indicate, however, that they are most used in the implementation and design of interventions, focus on technical aspects and process improvement. The instrumental use of evaluation findings prevails. Ferry and Olejniczak (2008) analysed six evaluations of EU-funded programmes (four ex post evaluations of pre-accession programmes, one interim evaluation of a pre-accession programme and one on-going evaluation of IRDOP) and demonstrated the limited use of the knowledge generated (the use of evaluation findings was more technical than strategic, also in reference to ex post evaluations). The following factors were found significant in supporting evaluation use: the presence of "strong, consistent, 'patronage' or support from the evaluation team in the Contracting Authority," institutional stability in the Contracting Authority, not combining evaluation of processes with evaluation of effects in the same research, and interactive evaluation processes.

The study "Evaluation of the system of application of recommendations by institutions involved in the implementation of the Sectoral Operational Programme Human Resources Development and the EQUAL Community Initiative Programme" (Ośrodek Ewaluacji Sp. z o.o. 2007) pointed out the lack of an effective system for implementing recommendations. There were no standards defining the way of using the knowledge obtained in the evaluation process, nor requirements to monitor putting into practice evaluation recommendations. This was also found to be a serious drawback of the system for implementation of cohesion policy 2004-2006 in the "Assessment of the cohesion policy 
implementation system 2004-2006" (EGO s.c. 2008). Thus, the extent of implementation of evaluation recommendations was difficult to determine. (However, following the study, an innovative model for implementation of evaluation recommendations was developed, but only in reference to OP Human Capital, which has been hailed as good practice; for more see: National Evaluation Unit, 2014a, pp. 32-33). The main objective of an evaluation, then, was to identify the barriers to EU funds absorption. It should be stressed that, prior to the Polish accession to the EU, evaluation of public interventions was a novelty for the Polish public sector. The evaluation requirements of cohesion policy support were the impulse to build evaluation capacity in Poland (National Evaluation Unit, 2014b). The fact that there was no national evaluation culture and it had to be taken 'from outside' is an important factor affecting the use of evaluation findings.

The study "Assessment of the cohesion policy implementation system 2007-2013" (EGO s.c. 2013) reveals that the main sources of information for the public authorities about public interventions were project control, monitoring and contact with beneficiaries. The low utilisation of evaluations was attributed to the lack of interest in research findings that go beyond process issues, focus on research delivery, which led to inflation of information, and not necessarily to a growth in knowledge. The provisions of the Public Procurement Act and its narrow interpretation were instrumental in the selection of evaluators with unsatisfactory qualifications, and the time stipulated for submitting evaluation reports was too short to prepare and consult their findings.

Kupiec (2014), in the study: "The use of evaluation in the operational programmes management. The case of regional operational programmes," on the basis of three case studies, verified key factors which enhance the use of evaluation. These are: (1) credibility of recommendations - the link between recommendations and conclusions, comprehensibility, the possibility of implementation, quality of methodology applied; (2) importance of the generated knowledge - whether recommendations relate to significant, positive changes or minor issues; and (3) adequacy of findings - fulfilment of recipients' expectations of information, completeness of reports, timing. He reported serious shortcomings in all three areas, which explains why evaluations do not fulfil their potential to support strategic decisions.

Similarly, the study on the use of evaluation findings in the European Commission indicates that evaluation findings contributed more to incremental changes than to significant changes in policy or the choice of policy options. They also did not lead substantially to efficient allocation of resources. The study was carried out in 2005, nevertheless, according to one of its authors - Bastin de Laat (de Laat, Williams, 2015, p. 153) it is still highly relevant today.

\section{Extending evaluation to regulatory interventions}

The European Commission is committed to evaluate EU spending as well as nonspending activities (regulatory interventions). The EU's Better Regulation agenda is about designing and evaluating EU policies and law in an open and transparent manner, and to which citizens and stakeholders have a chance to contribute throughout the whole policy cycle and law-making process. Importantly, the process should be backed up by 
evidence and understanding of the impacts, in order to ensure that the selected policy solution is the best and least burdensome way to achieve the intended objectives (European Commission, 2015). Although the idea of performing evaluations beyond expenditure policies dates back more than a decade, concrete measures for a more systemic application of evaluations to regulatory interventions have only been put forward more recently (see: Simismans, 2015).

First, the Commission publishes an indicative calendar of all planned evaluations of law, policies and spending programmes up to five years in advance. ${ }^{2}$ This forward planning of evaluations against the strategic priorities of the Commission is important from the point of view of enhancing the use of evaluation findings. Moreover, apart from evaluations of individual instruments, from $2012^{3}$ onwards, fitness checks of policy sectors are to be performed. These are comprehensive policy evaluations aiming at verifying "whether the regulatory framework for a policy sector is fit for purpose." To this end, a group of measures with a common set of objectives are evaluated together to identify the cumulative impact of legislation. In the process, "excessive regulatory burdens, overlaps, gaps, inconsistencies and obsolete measures which may have appeared over time" are to be revealed (European Commission, 2013b, p. 7). Beyond that, the Commission has established an "evaluation roadmap," which is the "project plan" for each evaluation, developed using a standard template, to ensure consistency in the level of information obtained from evaluation studies. They are published on a special web portal, where stakeholders have a chance to provide feedback (Roadmaps/Inception impact assessments).

The principles and good practice tips that the Commission follows when evaluating regulatory interventions are set out in the Better Regulations Guidelines (2015) and associated Better Regulation 'Toolbox'. Moreover, the quality of draft reports relating to major evaluations and fitness checks is reviewed by the Regulatory Scrutiny Board (RSB), an independent body of the Commission which consists of three high-level Commission officials and three experts recruited from outside the Commission. Contrary to the review of impact assessments of new initiatives, where the RSB issues an opinion (a positive opinion is required for an initiative accompanied by an impact assessment to be tabled for adoption by the Commission), in reference to evaluations and fitness checks of existing legislation, the RSB gives recommendations for improvement. They are also available on-line with the relevant evaluation reports. ${ }^{4}$

Evaluations, along with fitness checks, are important components of the Better Regulation Agenda and the Regulatory Fitness and Performance Programme (REFIT), which aims primarily to cut red tape and remove needless regulatory burdens. While it is widely argued that too much regulation can have adverse effects on market and economic growth, some authors claim that the approach taken by the Commission is not balanced (Vogel, Van den Abeele, 2010; Van den Abeele, 2015). The policy documents depict the acquis communautaire merely as a source of burdens and costs that weigh on the economy. The use of evaluation findings concentrates on the systematic reduction of regulatory costs and burdens, and not enough consideration is given to the potential benefits of EU legislation, not to mention that EU estimates are rather shaky. The view that

\footnotetext{
${ }^{2}$ See: e.g. Commission Forward Planning of Evaluations and Studies, 2016 and beyond.

3 Commission Communication, "EU Regulatory Fitness", COM (2012) 746 final.

${ }^{4} \mathrm{http} / / / \mathrm{ec}$.europa.eu/smart-regulation/evaluation/search/search.do.
} 
better regulation means less regulation is oversimplified, and paradoxically the BRA has generated its own bureaucracy. As Van de Abeele $(2015$, p. 9) acknowledges: the Better Regulation Agenda "has gradually become the foundation stone for those calling for less state intervention and a return to the national, regional or local level, with increasingly insistent demands for respect for subsidiarity and proportionality."

\section{Conclusions}

A number of EU documents demonstrate the role of evaluation in building and maintaining a culture of accountability and learning. As the European Commission (2014, p. 3) argues: "[e]valuation is a key learning tool for the European Union to understand not only what works and what does not, but critically why, and under what circumstances." It is important to learn from past experience and be able to recognise efficient and effective ways of operating. The recent Commission initiatives to improve evaluation revolve around two main areas: linking ex post evaluation with ex ante assessments, as well as extending evaluation to all types of policy-making, including regulatory interventions. This, however, seems to be very challenging. Taking the example of cohesion policy programmes implemented in Poland, it can be argued that evaluation findings were mostly used in the implementation and design of on-going interventions. The focus was more on technical aspects and process improvement than to support decision-making at strategic level. The same was found relevant in reference to the evaluations carried out by the European Commission itself. And as regulatory interventions are concerned, the use of ex post evaluations for new actions appears to be particularly visible in one area only - reducing regulatory costs and burdens.

In order to enhance the use of evaluation findings, several key factors can be distinguished, among others, timeliness of evaluation in reference to the programme or policy cycle, thus, the EU initiative of forward planning of all evaluations ('evaluation calendar') serves the purpose of ensuring stakeholder involvement - the Commission has increased the amount and length of public consultation, and has given the chance to provide feedback for every EU citizen or organisation from an early stage of the evaluation process (through 'evaluation roadmaps' and 'initial impact assessments'). However, in this regard, voices of concern have been expressed. Van den Abeele (2015, p. 26) describes the problem as "bypassing the democratic consultation chain, namely: member states' experts and social partners" (the European Economic and Social Committee and the Committee of the Regions), in favour of "a new category of actors whose legitimacy must be questioned, particularly as their influence will be difficult to monitor." The problem may be worth further investigation.

\section{Bibliography}

Bienias S., Gapski T., Jąkalski J., Lewandowska I., Opałka E., Strzęboszewski P. (2012), Ewaluacja. Poradnik dla pracowników administracji publicznej, Ministry of Regional Development, Warsaw.

Cairney P. (2012), Understanding Public Policy. Theories and Issues, Palgrave Macmillian China. 
De Laat B., Williams K. (2014), Evaluation Use Within the European Commission (EC): Lessons for the Evaluation Commissioner, in: Enhancing Evaluation Use. Insights from Internal Evaluation Units, eds. M. L. Loud, J. M. Mayne, Sage, pp. 147-174.

EGO s.c. (2008), Ocena systemu realizacji polityki spójności w Polsce w ramach perspektywy 20042006, Report commissioned by the National Evaluation Unit, Warsaw.

EGO s.c. (2013), Ocena systemu realizacji polityki spójności w Polsce w ramach perspektywy 20072013, Report commissioned by the National Evaluation Unit, Warsaw.

European Commission (2013b), Strengthening the foundations of Smart Regulation - improving evaluation, $\operatorname{COM}(2013) 686$ final.

European Commission (2015), Better Regulation Guidelines, Commission Staff Working Document. Com (2015) 215 final.

European Commission (2013a), Public consultation on Commission Guidelines for Evaluation, http:// ec.europa.eu/smart-regulation/evaluation/docs/20131111_guidelines_pc_part_i_ii_clean.pdf, 1.06.2016.

EVALSED (2013), The resource for the evaluation of Socio-Economic Development, http://ec.europa. eu/regional_policy/sources/docgener/evaluation/guide/guide_evalsed.pdf, 1.06.2016.

Ferry M., Olejniczak K. (2008), The use of evaluation in the management of EU programmes in Poland, Ernst\&Young, Warsaw.

Fournier D. M. (2005), Evaluation, in: Encyclopedia of Evaluation, ed. S. Mathisons, Sage, Thousand Oaks, Calif.-London, pp. 139-140.

Højlund S. (2015), For Accountability or Learning?, "European Journal of Risk Regulation”, vol. 6, issue 1, pp. 35-46.

Izdebski H. (2007), From public administration to public governance, "Zarządzanie Publiczne”, vol. 1, pp. 7-20.

Kupiec T. (2014), Wykorzystanie ewaluacji $w$ zarzqdzaniu programem operacyjnym na przyktadzie $R P O, \quad$ http://www.kozminski.edu.pl/fileadmin/Konferencje/Ewaluacja_pregramow_operacyjnych/2.WykorzystanieEwaluacjiRPOPolska_T.Kupiec.pdf, 30.06.2016.

Langbein L., C. L. Felbinger (2006), Public Program Evaluation. A statistical guide, M. E. Shape, New York-London

Markiewicz A., Patrick I. (2016), Developing Monitoring and Evaluation Frameworks, SAGE Publications Inc, USA.

Mayne J. (2014), Issues in Enhancing Evaluation Use, in: Enhancing Evaluation Use. Insights from Internal Evaluation Units, eds. M. L. Loud, J. M. Mayne, Sage, pp. 1-15.

National Evaluation Unit (2014b), Process of evaluation of the cohesion policy in Poland 2004-2014, Warsaw.

National Evaluation Unit (2014a), Impact of Evaluation on the Effectiveness and Efficiency of Implementation of the Cohesion Policy in Poland. Good Practices, Warsaw.

Olejniczak K. (2007), Ewaluacja jako narzędzie zarzqdzania w sektorze publicznym, in: Rozwój, region, przestrzeń, ed. A. Tucholska, Ministry of Regional Development, Warsaw, pp. 361-396.

Oleniczak K., M. Ferry (2008), Ewaluacja w praktyce sektora publicznego, in: Ewaluacja jako standard zarzadzania w sektorze publicznym, ed. B. Pietras-Goc, Wyższa Szkoła Europejska im. ks. Józefa Tishnera, Kraków.

Ośrodek Ewaluacji Sp. z o.o. (2007), Ocena systemu wdrażania rekomendacji przez instytucje zaangażowane w realizację Sektorowego Programu Operacyjnego Rozwój Zasobów Ludzkich 2004-2006 i Programu Inicjatywy Wspólnotowej Equal, Report commissioned by the National Evaluation Unit, Warsaw.

Patton M. Q. (2004), Evaluation research, in: The Sage encyclopedia of social science research methods, eds. M. S. Lewis-Beck, A. Bryan, T. F. Liao, Sage, Thousand Oaks, Calif., pp. 337-340. 
Roadmaps / Inception impact assessments, http://ec.europa.eu/smart-regulation/roadmaps/index_ en.htm, 30.07.2017.

Simismans S. (2015), Policy evaluation in the EU: The Challenges of Linking Ex Ante and Ex Post Appraisal, "European Journal of Risk Regulation", vol. 6, issue 1, pp. 6-26.

Stern E. (2009), Evaluation policy in the European Union and its institutions, "New Directions for Evaluation", issue 123, pp. 67-85.

Van den Abeele E. (2015), "Better Regulation": a bureaucratic simplification with political agenda, Working Paper 2015.04, European Trade Union Institute, Brussels.

Versluis E., van Keulen M., Stephenson P. (2011), Analyzing the European Union Policy Process, Palgrave Macmillan, London.

Vogel L., Van den Abeele E. (2010), Better regulation: a critical assessment, Report 113, European Trade Union Institute, Brussels.

\section{Nowe podejście do polityki ewaluacyjnej w Unii Europejskiej}

\section{Streszczenie}

Znacząca rola Unii Europejskiej w rozpowszechnianiu ewaluacji w Europie jest ogólnie uznana (Stern, 2009). Chociaż ewaluacja ma długoletnią tradycję w Unii, a zwłaszcza w Komisji Europejskiej, w ostatnich latach można zaobserwować proces jej ekspansji, dywersyfikacji i instytucjonalizacji.

Celem artykułu jest zbadanie nowych rozwiązań w dziedzinie polityki ewaluacyjnej w Unii Europejskiej, którą można scharakteryzować między innymi, wzmocnieniem powiązań między oceną wpływu ex ante i ex post, zamykając tym samym cykl polityki, w którym wnioski z ewaluacji ex post przekładają się na ocenę nowych przedsięwzięć publicznych. Stąd też, w artykule poruszony został problem wykorzystania wyników ewaluacji. Zakres ewaluacji również został rozszerzony i obejmuje nie tylko instrumenty związane z wydatkowaniem środków finansowych, ale także instrumenty regulacyjne. Ponadto, ewaluacji podlegają nie tylko pojedyncze programy czy projekty, ale polityki i grupy powiązanych ze sobą działań. W tym celu dokonano przeglądu literatury i dokumentów w dziedzinie teorii i praktyki ewaluacyjnej, w tym analizy przepisów prawnych regulujących praktykę ewaluacyjną w Unii Europejskiej.

Słowa kluczowe: ewaluacja, polityka oparta na dowodach, wykorzystanie wyników ewaluacji, lepsze stanowienie prawa 